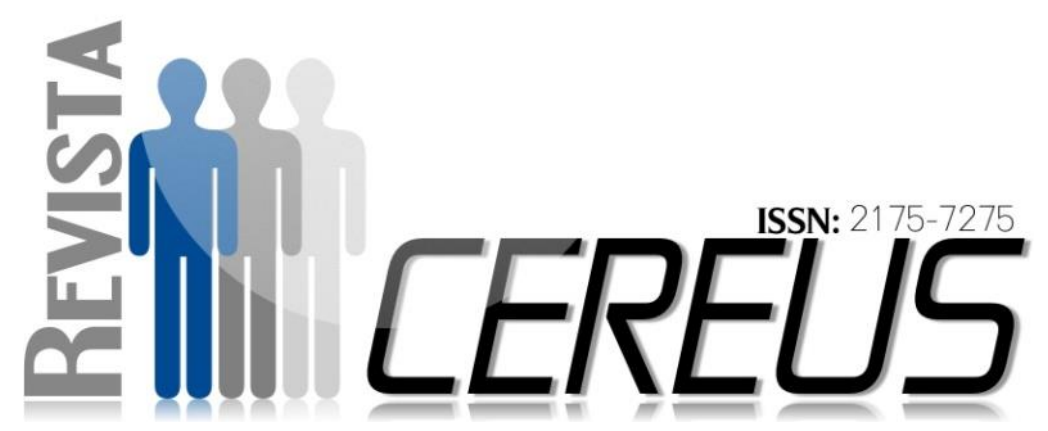

DOI: 10.18605/2175-7275/cereus.v9nep125-141.

\title{
PRELIMINARY STUDIES ON THE USE OF THE DIAGRAM RANK OF THE ORAL HEALTH OF THE BABY IN AN INTERDISCIPLINARY HEALTH PROGRAM
}

\author{
SILVA,Rosilene Teles ${ }^{1}$, \\ VILELA, Joana Estela Rezende ${ }^{2}$, \\ GAMA, Karla Regina ${ }^{3}$, \\ RANK, Marcos Sampaio ${ }^{4}$, \\ OGAWA, Wataro Nelson ${ }^{5}$ \\ RANK, Rise Consolação luata Costa 6 .
}

\section{ABSTRACT}

Considering the difficulty of recording intraoral data of edentulous children in dentistry, the Rank Diagram of the oral health of the baby was created and designed to meet this need. The present study aimed to verify registrations performed from 2012 to 2015, and also to understand the degree of examiner satisfaction. The research was carried out in two stages: 1) a cohort study with 138 charts completed during the intraoral examinations of children 0-36 months of age $(2012-2015) ; 2)$ the degree of satisfaction of the Diagram 1Graduada em Odontologia, Centro Universitário UnirG, Tocantins, Brasil.

2Mestre em Saúde Pública, UFG,GO; Departamento de Saúde Pública do curso de Medicina do Centro Universitário UnirG, Tocantins, Brasil.

3Especialista em Fonoaudiologia e Linguagem UNIFRAN,SP; Departamento de Odontopediatria do Centro Universitário UnirG, Tocantins, Brasil.

4Especialista em Prótese Dental, Departamento de saúde bucal do Município de Gurupi, Tocantins, Brasil.

5Doutor em Ciências (Fisiologia Humana), USP, SP; Departamento de Medicina do Centro Universitário UnirG, Tocantins, Brasil. 6Doutora em Odontopediatria UNICSUL, SP; Departamento de Odontopediatria do Centro Universitário UnirG, Tocantins, Brasil. Email: riserank@yahoo.com.br 
was verified by 33 examiners submitted to 6 months of filling out in 2016. The most frequent changes in the soft tissues were ankyloglossia (10.9\%) and inclusion cysts $(8.7 \%)$; as for the hard tissues, it was caries (8.6\%) and enamel fracture $(5.0 \%)$. The examiners verified the Rank Diagram as satisfactory $(89 \%)$, but the chi-square test showed significance in the dissatisfaction of the recording site of the observations in the Diagram $\left(p<0.0001\right.$ and $\left.x^{2}=59\right)$. The Rank Diagram allowed for the registration of the intraoral changes from the birth of the child until 3 years of age. The datasheet adapted to the quarterly program was preliminarily well evaluated in several aspects, but requires some adjustments to improve the recording space of the intraoral observations.

KEY-WORDS: Primary Prevention, Oral Health; Child Health

\section{RESUMO}

Considerando a dificuldade de registro de dados intrabucais de crianças edentadas em odontologia, o Diagrama Rank da saúde bucal do bebê foi criado e idealizado para suprir esta necessidade. A presente pesquisa visou verificar registros realizados de 2012 a 2015, e também perceber o grau de satisfação dos examinadores. A pesquisa foi realizada em duas etapas: 1) estudo coorte, com 138 prontuários preenchidos durante os exames intrabucais de crianças de 0 a 36 meses de idade (2012-2015); 2) verificou-se o grau de satisfação do Diagrama por 33 examinadores submetidos a 6 meses de preenchimento em 2016. As alterações mais encontradas em tecidos moles foram anquiloglossia (10,9\%) e cistos de inclusão (8.7\%), quanto aos tecidos duros foi a 
cárie $(8.6 \%)$ e fratura de esmalte $(5.0 \%)$. Os examinadores aferiram o Diagrama Rank como satisfatório (89\%), mas o teste Qui-quadrado demonstrou significância na insatisfação do local de registro das observações no Diagrama $(p<0,0001$ e $x^{2}=59$ ). O Diagrama Rank possibilitou o registro de alterações intrabucais do nascimento da criança até os 3 anos de idade. A ficha adaptada ao programa trimestral foi preliminarmente bem avaliada em vários quesitos, mas requer alguns ajustes para melhorar o espaço de registros das observações intrabucais.

PALAVRAS-CHAVE: Prevenção primária, Saúde oral, Saúde da criança. 


\section{INTRODUCTION}

Newborns present some those who began treatment with characteristics that are adequate for the children from 0 to 6 months were more physiological needs of this period, effective in reducing childhood oral inherent to their phase of oral development (SILVA et al., 2008). The baby's mouth undergoes numerous changes during the anatomical and physiological development, and numerous specific pathologies of this period of life may arise. Most of these changes do not require curative treatment, only professional follow-up, and it is necessary to use tools that make these records possible (GOMEZ et al., 2010).

Early dental care must occur even in the first year of life, and can start from the birth of the child with a few days or months of life, even in maternity wards. Babies are examined by an interdisciplinary team of trained professionals who point out the first educational advices or due to the existence of any changes or anomalies that are referred to treatments (LEMOS et al., 2014). The literature review of early dental care programs in Brazil diseases. Following this trend, it is important that health professionals possess the necessary knowledge about the morphological characteristics of the normal patterns of the oral cavity of a newborn (BESSA et al., 2004).

The professionals who care for the oral health of edentulous children do not have a tool to record information on the general state of this oral cavity. Thus, the professor and researcher in the Rise Rank Pediatric Dentistry University Center UnirG, developed a diagram to enable the registration of the collection of data. In this way, it became the aim of the present study to preliminarily analyze the use of the Rank Diagram of the oral health of the baby in a public program, verifying if the instrument was able to register the changes in the soft and hard tissues of the oral cavity of the children in the first years of life and assess the degree of examiner satisfaction.

(RANK et al., 2015) has shown that all 


\section{METHODS}

The present prospective cohort study was conducted on 138 charts with the Rank Diagram filled out in a program and promotion in oral health called "Boquinha do bebê." The program takes place within the public health network in the city of Gurupi (TO) in the Legal Amazon region, covering the micro region of Bananal Island, with an area of $1,836,091$ square kilometers and a total population of 84,628 people ( IBGE / 2016). The children have been enrolled in this public program since birth. The professionals performed the treatment of edentulous children, and all of them received clinical examination, oral cleaning and quarterly control. The project also guided mothers regarding a diet and they received a returning card. The professionals followed the child's dental eruption, occlusion stabilization and monitored them up to five years old, if any changes were detected during this period, the staff intervenes according to the dental standards of the American Academy of Pediatric Dentistry (American Academy of Pediatric Dentistry, 2008).

The study was approved by the Research Ethics Committee with
Humans of the UnirG, University Center, protocol number 50681115.7.0000.5518.

The Rank Diagram of the oral health of the baby consists of a sketch of the oral cavity illustrated to enable registration with codes and captions, in order to identify and locate intraoral changes of the babies. It has a schematic drawing of the mouth of an edentulous child, with the gingival rotators, tongue, lingual brake, lips, and places suggestive of tooth eruption, but there is no drawing of the presence of teeth. This diagram was created to record, in a practical and simple way, the physiological (dental eruptions) and non-physiological (changes and pathologies) events of the oral cavity of children 0 to 3 years old. The scheme allows that as soon as the teeth are bursting in the oral cavity, the examiner registers each dental element, which allows the monitoring of the time of eruption of each tooth.

The diagram was prepared for use in the epidemiological control and cohort of the "Boquinha do bebê" program, which is also part of a university extension project with the participation of undergraduate students in dentistry. The Diagram has been adapted for 
quarterly follow-ups and has been used in print for oral examinations since 2012 (Figure 1). This diagram is accompanied by a brief guidance manual.
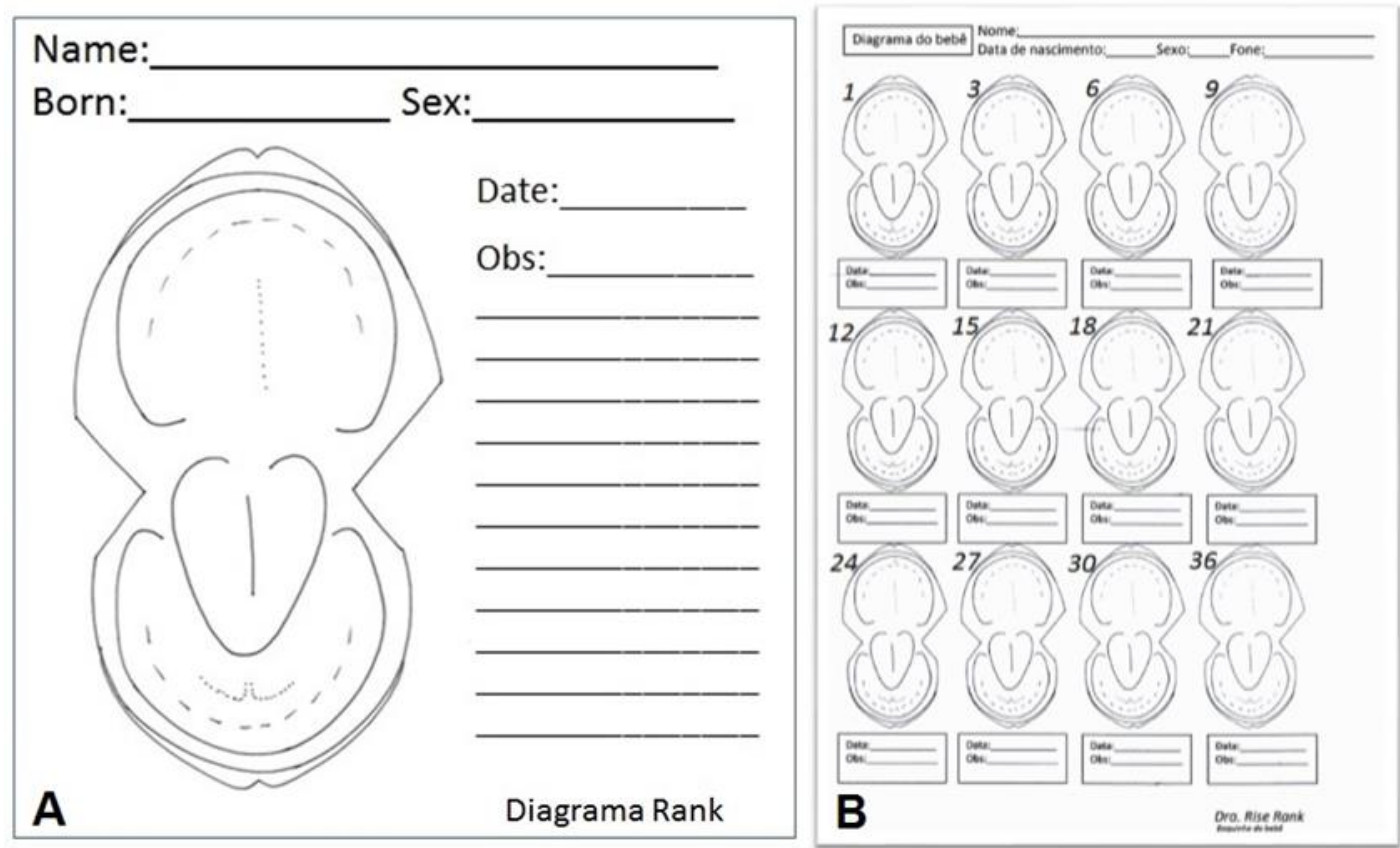

Figure 1: (A) - Schematic drawing of an edentulous child's mouth (individual examination); (B) - Rank Diagram adapted to the children's oral health quarterly follow-up program, from 0 to 36 months of age.

The sample of the present preliminary study was carried out in two stages: Step 1 - documentary analysis; Step 2 - filling in the questionnaire by examiners.

Step 1 - Criteria for inclusion of the records were: Anamnesis and Rank Diagram of children from 0 to 36 months, fully completed and with a minimum of 3 visits to the program, from February 2012 to December 2015. Excluded Diagrams of children completed by up to 2 visits to the Health
Promotion Program. Of the 448 completed records, 214 had two or fewer visits to the program due to abandonment or recently initiated, and 96 records with anamnesis, but without the Rank Diagram. In the inclusion criterion, 138 charts were included with diagrams, 63 of the female gender and 75 of the male.

The completed diagrams were analyzed by a single evaluator. The authors chose to verify the data of changes of the soft tissues and the hard 
tissues, respecting the time that was detected and marked in the diagram by the professional.

Step 2 - In 2016, the academics of the last period of the dentistry course were trained with the instrument manual and had the experience of filling out the Diagram during the participation of the program of care for the baby for 6 months.

The included examiners were the three dental professionals and thirty dental academics attending at least 6 months in the program, after formal consent and signing of the Informed Consent Term (TCLE); they were submitted to this preliminary study by filling out a form with 13 questions about the degree of satisfaction of the Rank Diagram $(A=$ Very satisfied, $B=$ Satisfied, $\mathrm{C}=$ Unsatisfied, $\mathrm{D}=$ Unsatisfied and $E=$ Very dissatisfied).

\section{RESULTS}

The study showed in table 1 the results of the 138 diagrams in a descriptive way, with the presentation of the main data obtained in intraoral clinical exams and with registration in the respective age groups in which they were found. In the statistical analysis of the data presented in Table 1, these do
The verified items were: Internal design of edentulous mouth; Locations for registration of erupted teeth; Record of lesions in the gingival tract; Record of lesions or tongue changes; Record changes in lips; Registration of changes in the frenulum; Record of changes in the palate; Quarterly follow-up of oral alterations; Quarterly follow-up of dental eruptions; Instruction manual; Place to record observations; Practicality for recording oral changes; Sheet printed on A4 paper.

The data were tabulated in the Epilnfo, the results' analysis was performed in a descriptive way with table presentation, and the chi-square test was used to evaluate the degree of satisfaction between the examiners regarding the Rank Diagram instrument with the level of significance less than $5 \%$.

not fit into the rigor of the criteria for the use of the chi-square because there are cases where the frequencies are null with very small expected values; the $\mathrm{G}$ test was applied at a significance level of $5 \%$, and for this, the gender of children was not taken into account. 
Table 1: Distribution in numbers of the main data obtained in the intraoral clinical exams in relation to hard and soft tissues in the respective age groups in which they were found.

\begin{tabular}{|c|c|c|c|c|c|c|c|c|c|}
\hline \multirow[t]{2}{*}{$\begin{array}{l}\text { HARD } \\
\text { TISSUE }\end{array}$} & \multirow[t]{2}{*}{ ALTERATION } & \multicolumn{2}{|c|}{$\begin{array}{c}0-12 \\
\text { Months }\end{array}$} & \multicolumn{2}{|c|}{$\begin{array}{c}13-24 \\
\text { Months }\end{array}$} & \multicolumn{2}{|c|}{$\begin{array}{c}25-36 \\
\text { Months }\end{array}$} & \multicolumn{2}{|c|}{ Total } \\
\hline & & $\mathbf{F}$ & $\mathbf{M}$ & $\mathbf{F}$ & $\mathbf{M}$ & $\mathbf{F}$ & $\mathbf{M}$ & $\mathrm{n}$ & $\%$ \\
\hline \multirow[t]{6}{*}{ Tooth } & 1.Carie & & 01 & 02 & & 04 & 05 & 12 & 8.6 \\
\hline & 2. Dental traumatic injuries & 01 & 01 & 01 & 03 & & 01 & 07 & 5.0 \\
\hline & 3.Agenesis & & & 01 & 01 & & 01 & 03 & 2.1 \\
\hline & 4. Enamel hipocalcification & & 02 & 01 & & & & 03 & 2.1 \\
\hline & 5. Enamel hypoplasia & & & 01 & 01 & & & 02 & 1.4 \\
\hline & 6. Geminated' and 'fused' teeth & & 01 & 02 & & & & 03 & 2.1 \\
\hline \multirow{2}{*}{\multicolumn{10}{|c|}{$\begin{array}{l}\text { SOFT } \\
\text { TISSUE }\end{array}$}} \\
\hline & & & & & & & & & \\
\hline \multirow{3}{*}{$\begin{array}{l}\text { Gingival } \\
\text { diseases }\end{array}$} & 7.Gingivitis & 02 & 02 & 01 & 03 & & 01 & 09 & 6.5 \\
\hline & 8.Gingival margin & 02 & 02 & & & & & 04 & 2.8 \\
\hline & 9.Língua Geográfica & 02 & 01 & 02 & 01 & & & 06 & 4.3 \\
\hline \multirow[t]{2}{*}{ Tongue } & 10. Ankyloglossia & 05 & 10 & & & & & 15 & 10.8 \\
\hline & 11. Congenital lower-lip pits. & 06 & 04 & 01 & & & & 11 & 7.9 \\
\hline \multirow[t]{2}{*}{ Lip } & 12. Fibrosis of the lips & & & & & 01 & & 01 & 0.7 \\
\hline & 13.Mucocele & 01 & & & 01 & 01 & & 03 & 2.1 \\
\hline \multirow[t]{3}{*}{ Cysts } & 14. Eruption cysts & 01 & 01 & 01 & 02 & & & 05 & 3.6 \\
\hline & $\begin{array}{l}\text { 15. Inclusion cysts (Epstein's } \\
\text { pearls, Bohn's nodules) }\end{array}$ & 06 & 05 & 01 & & & & 12 & 8.7 \\
\hline & 16. Ranula & 01 & & & & & & 01 & 0.7 \\
\hline
\end{tabular}

The correlation established between the intra-oral clinical examination in the 0 to 3 age group showed significance with $\mathrm{G}=88.5(\mathrm{p}$ $<0.0001$ ) and $\mathrm{G}$ (of Williams) $=67.2$ with $p=0.0001$. The residue analysis applied to the set of observed results in relation to the frequency of the expected data is shown in Table 2.

Changes in the hard tissues in the caries predominated, and it was observed that the older the age in months, the greater the appearance of teeth affected by caries. Dental trauma had a higher occurrence in the first 24 months of life and changes in tooth shape, such as germination and fusion, were also found in these children. Of the soft tissue abnormalities, ankyloglossia had the highest incidence, followed by inclusion cysts, in which these diagnoses occurred as early as the first months of the child's life. It has been observed that soft tissue injuries are more common at younger ages. 
Table 2: The adjusted values residues (Raj) were obtained from standardized residuals values to each cell of Table 1, with reference to the normal distribution reduced to $5 \%$ significance level (1.96).

\begin{tabular}{|c|c|c|c|}
\hline & $\begin{array}{c}0-12 \\
\text { Meses }\end{array}$ & $\begin{array}{c}13-24 \\
\text { Meses }\end{array}$ & $\begin{array}{c}\text { 25-36 } \\
\text { Meses }\end{array}$ \\
\hline 1. & $-3.8^{*}$ & -0.8 & $6.4^{*}$ \\
\hline 2. & -1.7 & 1.9 & 0 \\
\hline 3. & $-2.1^{*}$ & 1.6 & 0.9 \\
\hline 4. & 0.3 & 0.3 & -0.7 \\
\hline 5. & -1.7 & $2.4^{*}$ & -0.6 \\
\hline 6. & -0.9 & 1.6 & -0.7 \\
\hline 7. & -0.9 & 1.3 & -0.3 \\
\hline 8. & 1.7 & -1.2 & -0.8 \\
\hline 9. & -0.5 & 1.3 & -1.0 \\
\hline 10. & $3.5^{\star}$ & $-2.5^{*}$ & -1.7 \\
\hline 11. & $2.3^{*}$ & -1.4 & -1.4 \\
\hline 12. & -1.2 & -0.6 & $2.4^{*}$ \\
\hline 13. & -0.9 & 0.3 & 0.9 \\
\hline 14. & -0.9 & 1.7 & -0.9 \\
\hline 15. & $2.5^{\star}$ & -1.5 & -1.5 \\
\hline 16. & 0.8 & -0.6 & -0.4 \\
\hline
\end{tabular}

Table 3: Distribution in numbers of the perception on the arbitrary scale of the degree of satisfaction, according to the indicators shown in the Rank Diagram.

\begin{tabular}{llcc|cccc}
\multicolumn{1}{c}{ Series } & \multicolumn{1}{c}{ *Indicators } & A & B & C & D & E \\
\hline GI & Design of edentulous mouth & 22 & 10 & $\mathbf{1}$ & & \\
& Locations for registration of erupted teeth & 17 & 13 & $\mathbf{2}$ & $\mathbf{1}$ & \\
& Record of lesions in the gingival tract & 15 & 14 & $\mathbf{2}$ & $\mathbf{2}$ & \\
& Record of lesions or tongue changes & 23 & 10 & & & \\
& Record changes in lips & 18 & 10 & $\mathbf{3}$ & $\mathbf{2}$ & \\
& Registration of changes in the frenulum & 24 & 7 & $\mathbf{1}$ & $\mathbf{1}$ & \\
& Record of changes in the palate & 23 & 8 & $\mathbf{2}$ & & \\
\hline GII & Quarterly follow-up of oral alterations & 27 & 5 & $\mathbf{1}$ & & \\
& Quarterly follow-up of dental eruptions & 21 & 11 & $\mathbf{1}$ & & \\
\hline GIII & Instruction manual & 8 & 20 & $\mathbf{4}$ & & $\mathbf{1}$ \\
& Place to record observations & 7 & 6 & $\mathbf{1 0}$ & $\mathbf{6}$ & $\mathbf{4}$ \\
& Practicality for recording oral changes & 22 & 10 & & $\mathbf{1}$ & \\
& Sheet printed on A4 paper & 23 & 8 & $\mathbf{2}$ & & \\
\hline
\end{tabular}

${ }^{*} A=$ Very satisfied, $B=$ Satisfied, $C=$ Unsatisfied, $D=$ Unsatisfied and $E=$ Very dissatisfied . 
Table 3 presents the general data obtained (counting individuals) from the perception on the arbitrary scale of the degree of satisfaction, according to the indicators shown in the Rank Diagram. The indicators were grouped and evaluated in three series of analysis shown as GI, GII and GIII, respectively.

The satisfaction scale was modified as: $\mathrm{A}=$ "very satisfied", $\mathrm{B}=$ "satisfied" and C, D, E were grouped as "unsatisfied" to fit within the established criteria and appropriate use of the chisquare test. The chi-square test at the $5 \%$ level applied to the data from the indicators in sphere I showed a nonsignificant result $\left(p=0.261, X^{2}=14.65\right)$, demonstrating that there were no discrepancies or disproportions in the examiner satisfaction scale.

The Gll resulted in a composition of type 2 by 2 regarding the level of satisfaction very satisfied and satisfied. Due to these characteristics, the chisquare test was followed by the requirement of the Yates correction, where it was shown that the satisfaction indexes and the two indicators grouped as quarterly follow-ups of this population were not correlated at the $5 \%$ level $(p=0.167$ and $x 2=1.91)$.

The GIII data evidenced an association between the satisfaction indexes with grouped indicators ( $p$ $<0.0001$ and $x^{2}=59$ versus $p=0.05$ and $X^{2}=12.59$ ) at a significance level of $5 \%$. This result shows a disproportion or disagreement in the satisfaction responses of the examiners regarding these indicators.

The results of the adjusted residue analysis (Raj) are presented in Figure 2, where Raj values greater than 1.96 are significant for more or less as to the proportions of responses obtained in the satisfaction scale. In this way, the instruction manual in the Rank Diagram showed a lower proportion of "very satisfied" than expected. As for the local indicator for recording observations, the ratios of "dissatisfied" were significantly higher than that normally expected at random. The practicality for recording graphic changes in the mouth showed significance in the proportion of the "very satisfied" index and the same result was observed in the indicator tab printed on A4 paper. 


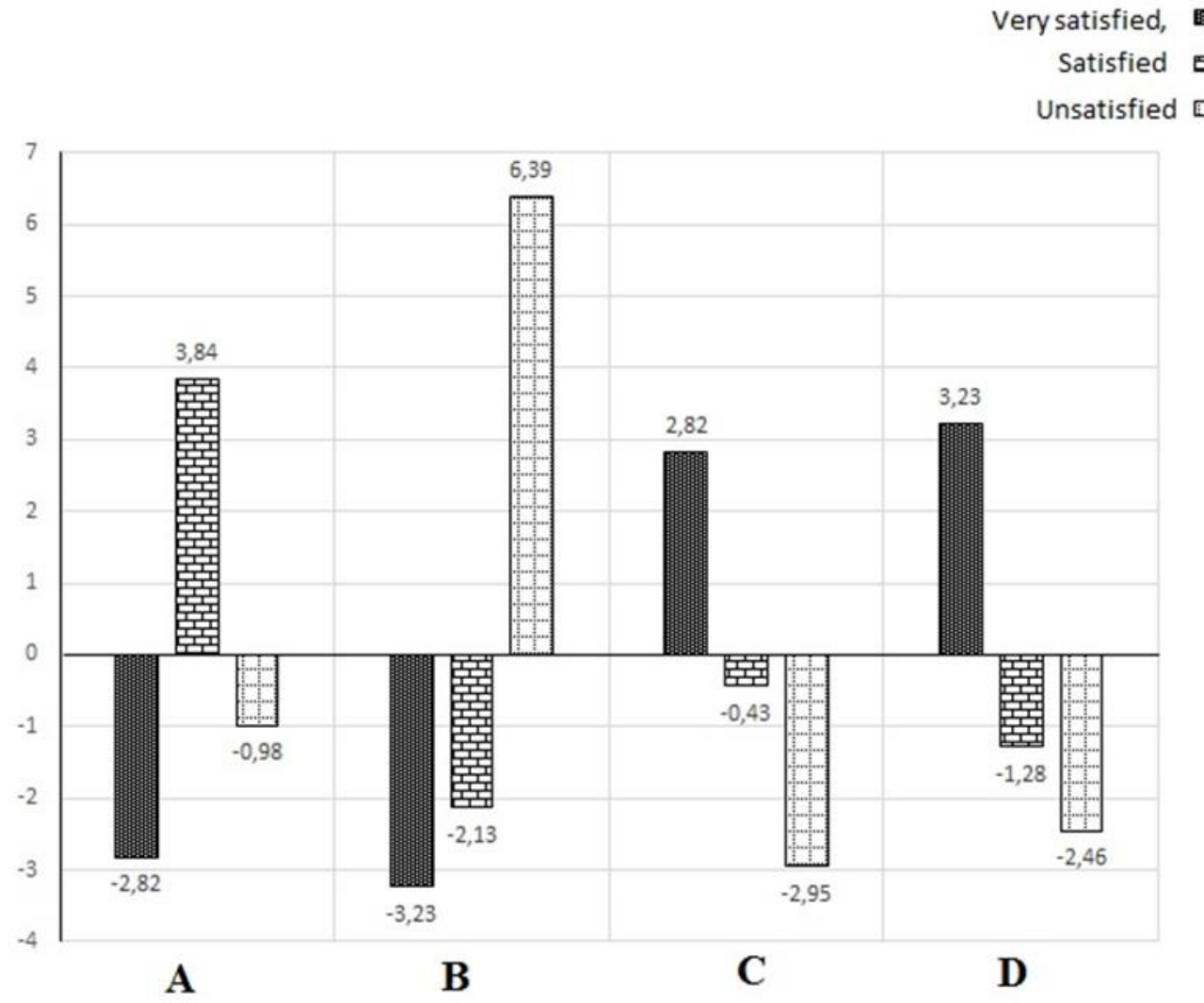

$A=$ Instruction manual; $B=$ Place to record observations; $C=$ Practicality for recording oral changes; $D=$ Sheet printed on $A 4$ paper

Figure 2. Residual analysis: The values of Raj (adjusted residuals) were obtained from standardized residue values for each cell of Table 4, with reference to standard normal distribution at $5 \%$ significance $($ Raj $=1.96)$.

\section{DISCUSSION}

The Expert Committee on Dental Health and the World Health Organization (WHO) in 1961 presented the first proposal to formulate standardization methods for the description of oral diseases (WHO, 2003). Epidemiological surveys in oral health, considering the regional differences with regard to the model of development of oral diseases, different

methodologies of studies, technical and scientific knowledge and diverse samplings led the WHO to encourage the establishment of standards of procedures that can be used in all countries. In Brazil, since the 1980s, epidemiological surveys have been carried out nationwide to evaluate the oral health conditions of the population, and the last survey with a 
representative sample of five-year-old children $(\mathrm{n}=7,217)$ in 177 municipalities was in 2010 (ARDENGHI et al., 2013).

The lack of a resource that allowed the recording of the data collected during the quarterly diagnosis in children from zero to three years in the "Boquinha do Bebê" program was what led to the development of this Diagram. The authors believe that because of this absence, many areaspecific data may have been neglected and / or lost during clinical exams since 2007 when the Oral Health Program began, in that they were only handwritten in printed pediatric dentistry records. The lack of a standard form also makes it difficult to exchange information with colleagues who work in other locations, since each region presents a type of medical record with different forms of data records, which prevent epidemiological publications and dissemination in an aligned and standardized way with other similar care programs (BAKER, GIBSON et al., 2014).

Babies' parents have sought dentists to receive information about their children's oral health because in addition to seeking prevention, they may often have observed some abnormality or changes in the child's mouth. The normal oral characteristics of a newborn according to his stage of development is not well known by the parents but must be well understood technically by the professional (ABANTO et al., 2009).

Morphological and tissue changes can cause functional limitations, such as feeding difficulties and stimulation of lesions, which is why early diagnosis is important (MOUCHREK et al., 2011). Epstein pearls, Bohn's nodules, congenital epulis, birth teeth, mucocele, rnaula, ankyloglossia, and persistent lip breaking are considered abnormalities or anomalies found in the child's mouth, some of which should be treated and others only controlled (SCHMITT et al., 2012; CIZMECI et al., 2014). In other situations, some alterations require surgical interventions such as braces and flanges with inadequate insertion, presence of neonatal teeth or mobile natives with indication of extraction (VAN HEERDEN, VAN ZYL 2010), which certainly means minimizing or avoiding greater complications in the health of the child.

Although the oral cavity of the edentulous baby has not yet been colonized by cariogenic bacteria, the 
frequency of oral soft tissue changes in children is high and increases with age, and some of them are associated with the patients' medical history and habits (ARROW, 2016). Changes in younger children were more common in the soft tissues than in hard tissues. Eruption cysts are benign, appear before the eruption of deciduous or permanent teeth $^{16}$ and are usually asymptomatic, requiring only control and follow-up of the case, but if this cyst promotes pain in the child, a simple surgical incision is indicated (SEN-TUNÇ et al., 2017).

Regarding the oral soft tissue changes in the present study, the most frequent recorded in the diagram was ankyloglossia. For diagnosis, the classification of "tongue test" (MARTINELLI et al., 2012) ${ }^{18}$ was used, in which professionals, according to the result, indicated the follow-up or surgery. The diagram showed presence of ankyloglossia in a child of 03 months, but at 18 months of age the registered exam reported no need for a surgical procedure for correction. However, even though a frenulotomy was not required, the accompaniment and professional knowledge to reassure the family members was important. Twelve of these children have received the frenotomy and the others have been accompanied by the program so far. This change is not considered uncommon in infants, but in a systematic review of the literature, the authors realized the absence of comparative studies to evaluate the efficacy of follow-ups of children without performing surgical treatment with those who received the frenotomy or frenectomy (FRANCIS et al., 2015).

Dental caries in early childhood, depending on the severity, may interfere with the development and growth of children (FELDENS et al., 2010). Global data report that caries in children increases with the number of years (PETERSEN, 2005), coming to the findings of the present study, which found a higher prevalence of caries with increasing age. However, the diagram allows for the identification of the teeth affected by caries, but it does not make it possible to register the affected faces in the dental element, since the dentist himself draws the tooth. Since the diagram manual does not guide this information, the examiner did not record the injured face.

The Rank Diagram recorded hypoplasia in the teeth 51,61 in a 1 year-old child and 52 in a 4-year-old child, in whom the pre-maturity factor may be related. On the other hand, 
hypocalcification was recorded in the observations, but neither the identification of the affected tooth nor the faces was recorded. One study evaluated 600 deciduous teeth, and hypocalcification was found in only 10 elements belonging to 5 children, of these ten teeth, the marked opacity was found in 6 of the teeth affected by enamel defects, followed by hypoplasia in 4 of the cases (BARBOSA et al., 2008; MACHADO et al., 2013) ). It was clear that, for the effectiveness of the use of this diagram, the professional qualification to collect and register these data is necessary, because in some diagrams, the failure by the examiner's attention was perceived, which promoted doubt in the moment of follow-up of the oral changes by these students.

Health promotion and prevention programs achieve better results when they allow referral to specialties, and the post-treatment follow-up of the child (GOMEZ et al., 2010) becomes important. This fact was also contemplated by the "Boquinha do Bebê" program, where the children diagnosed with lesions and pathologies for restorative or surgical interventions were referred to the Center of Dental Specialties (CDS) and the Rank
Diagram allowed, with their records, child control after the interventions.

According to the professionals and academics who filled out the diagram, this instrument allowed to follow the period of dental eruption of the children of the program, the control of the children's oral changes, and several pathological events of the oral cavity were recorded in children from 0 to 3 years of age, but the study showed the need for more room for data records. It was clear that, for the effectiveness of the use of this diagram, professional qualification to collect and record the findings is necessary, because in some diagrams the failure by the examiner's attention was perceived, which promoted doubt in the moment of follow-up of the oral changes by these students. The set of information on the history of oral and general health recorded in the medical records and patient records, as well as the procedures performed, serves to verify the clinical evolution of the treatment. These data can be used for scientific and epidemiological work in a community, since the professional examiner's attention is indispensable in filling clinical records (COSTA et al., 2009). 
For the effectiveness of standardization actions in diagnosis, it is important to carry out further tests

\section{CONCLUSIONS}

The present preliminary study allowed us to know the Rank Diagram of the oral health of the baby as a new proposal for recording data of oral clinical exams in children from 0 to 36 months. This instrument recorded physiological events and oral cavity changes in children participating in a and research in order to understand and make possible the improvement of this registry instrument.

quarterly frequency oral health promotion program.

The record adapted to the program was preliminarily well evaluated in several questions by the examiners, but evidenced the need for adjustments to give more space to the records of the intraoral observations.

\section{REFERÊNCIAS}

ABANTO, J.; RAGGI, D.P.; ALVES, F.B.T.; CORRÊA, F.N.P.; BÖNECKER, M.; CORREAA, M.S.N.P. Oral characteristics of newborns: report of some oral anomalies and their treatment. Int. J. Dent., v.8, n. 3, p.140-145, 2009.

AMERICAN ACADEMY OF PEDIATRIC DENTISTRY. Definition of early childhood caries (ECC). Pediatric Dentistry, v.30, n.7, p.13. 2008.

ARDENGHI, T.M.; PIOVESAN, C.; ANTUNES, J.L.F. Inequalities in untreated dental caries prevalence in preschool children in Brazil. Revista de Saúde Pública, v.47; n.3, 2013, p. 129-137.

ARROW, P. Responsiveness and sensitivity of the Early Childhood Oral Health Impact Scale to primary dental care for early childhood caries. Community Dent. Oral Epidemiol.v,44, 2016, p.1-10.

BAKER, S.R.; GIBSON, B.G. Social oral epidemiology where next: one small step or one giant leap? Community dentistry and oral epidemiology, v. 42, n.6, 2014, p.481494. 
BARBOSA, D.M.L.; LEMOS, L.V.F.M.; BANZI, E.C.F.; MYAKI, S.I. Prevalence of enamel hypoplasia in primary teeth of prematurely-born children. Rev. Odontol. UNESP, v.37, n.3, 2008,p. 261-265.

BESSA, C.F.L.; SANTOS, P.J.; AGUIAR, M.C.; CARMO, M.A. Prevalence of oral mucosal alterations in children from 0 to 12 years old. J. Oral Pathol. Med., v. 33, n.1, 2004, p.17-22.

CIZMECI, M.; KANBUROGLU, M.; KARA, S.; TATLI, M. Bohn's nodules: peculiar neonatal intraoral lesions mistaken for natal teeth. European Journal of Pediatrics, v.173, n.3, 2014, p.403.

COSTA, S.M.; BRAGA, S.L.; ABREU, M.H.N.G.; BONAN, P.R.F. Questões éticas e legais no preenchimento das fichas clínicas odontológicas. R.G.O., v.57, n.2, 2009, p.211-216.

FELDENS, C.A.; GIUGLIANI, E.R.; VIGO, Á.; VÍTOLO, M.R. Early feeding practices and severe early childhood caries in four-year-old children from southern Brazil: a birth cohort study. Caries Res. 2010; v.44, n.5, 2010, p.445-452.

FRANCIS, D.O.; KRISHNASWAMI, S.; MCPHEETERS, M. Treatment of ankyloglossia and breastfeeding outcomes: a systematic review. Pediatrics. http://pediatrics.aappublications.org/content/early/2015/04/28/peds. 2015, p.658. GOMEZ, F.J.R.; CRYSTAL, Y.O.; CRALL, J.J.; FEATHERSTONE, J.D.B. Pediatric Dental Care: Prevention and Management Protocols Based on Caries Risk Assessment. J Calif Dent Assoc. 2010; v.38, n.10, 2010, p.746-761.

LEMOS, L.V.; MYAKI, S.I.; WALTER, L.R.; ZUANON, A.C. Oral health promotion in early childhood: age of joining preventive program and behavioral aspects. Einstein, v.12, n.1, 2014, p.6-10.

MACHADO, A.A.C.; COSTA, B.R.; GOMES, L.R.G.; FRAGELLI, C.M.B. Prevalence and etiology of developmental defects of enamel in deciduous and permanent teeth. Uninga Review, 2013; 15 (1): 2013, p.48-54.

MARTINELLI, R.L.C.; MARCHESAN, I.Q.; BERRETIN-FELIX G. Lingual Frenulum Protocol with scores for infants. Int. J. Orofacial Myology, v.38, 2012, p.104-112.

MOUCHREK, M.M.M.; GONÇALVES, L.M.; BEZERRA-JÚNIOR, J.R.S.; MAIA, E.D.C.S.; SILVA, R.A.D.; CRUZ, M.C.F. Oral and maxillofacial biopsied lesions in Brazilian pediatric patients: a 16-year retrospective study. Revista Odonto Ciência, v.26, n.3, 2011, p.222-226. 
NAGAVENI, N.B.; UMASHANKARA, K.V.; RADHIKA, N.B.; SATISHA, T.M. Eruption cyst: A literature review and four case reports. Indian J. Dent. Res., v.22, 2011, p.148. PETERSEN, P.E. Priorities for research for oral health in the 21st Century-the approach of the WHO Global Oral Health Programme. Community Dent. Health, v.22, n.2, 2005, p.71-74.

RANK, R.C.I.C.; MENDES, L.M.C.; VILELA, J.E.R.; RANK, M.S.; MOLINA, O.F. Programas de atendimento odontológico precoce no brasil, uma revisão de literatura. Revista Cereus, v.7, n.1, 2015, p.160-176.

SCHMITT, B.H.E.; GUZZI, S.H.; DAMO, M.N.; ARAÚJO, S.M.; FARIAS, M.M.A.G. Characteristics of the Oral Cavity of the Newborns of Blumenau-SC, Brazil. Pesq. Bras. Odontoped. Clin. Integr., v.12, n.1, 2012, p.89-92.

SEN-TUNÇ, E.; AÇIKEL, H.; ŞAROĞLU-SÖNMEZ, I.; BAYRAK, Ş.; TÜLOĞLU, N. Eruption cysts: A series of 66 cases with clinical features. Medicina Oral, Patología Oral y Cirugía Bucal, v.22, n.2, 2017, p.228.

SILVA, C.M.; RAMOS, M.M.; DE CARVALHO, C.; FELÍCIO, C.; DA SILVA DALBEN, G. Oral characteristics of Newborns. Journal of Dentistry for Children, v.75, n.1, 2008, p.4-6.

VAN HEERDEN, W.F.; VAN ZYL, A.W. Diagnosis and management of oral lesions and conditions in the newborn: CPD article. South African Family Practice, v.52, n.6, 2010, p.489-491.

W.H.O. The World Oral Health Report. Continuous improvement of oral health in the 21st century - The approach of the WHO Global Oral Health Programme. Geneva: World Health Organization, v.3, 2003.

Recebido em: 19/07/2017

Aprovado em: 01/02/2018 